\title{
BIODIVERSITY OF TREES AND SHRUBS OF URBAN PLANTATIONS IN ARID REGIONS
}

\author{
Mohammed Souddi ${ }^{1, *}$, M'hammed Bouallala $^{1}$ \\ ${ }^{1}$ Saharan Natural Resources Laboratory, University of Adrar, 1000, Algeria, \\ Faculty of Sciences and Technology, Department of Nature \\ and Life Sciences, Adrar, Algeria
}

\begin{abstract}
Trees and shrubs are essential components in the production of ecosystem services. The aim of this study is to evaluate the biodiversity of plantations in arid regions. A floristic inventory was carried out in three biotopes using an exhaustive sampling approach. Diversity parameters were calculated to assess phytodiversity in each biotope. A total of 23 plants species belonging to 17 families, with a dominance of eudicots at $95.65 \%$ were recorded. The dominant families were Fabaceae (17.38\%), Arecaceae, Lythraceae and Tamaricaceae (8.69\%). The flora was mixed with $56.52 \%$ of exotic plant species. The most predominant plant species were Phoenix dactylifera L, Tamarix aphylla (L.) H. Karst, Dodonaea viscosa (L.) Jacq, and Leucaena leucocephala (Lam.) de Wit, these species accounted for $72.74 \%$ of all individuals inventoried. Shannon's diversity index and Piélou index of evenness range from 2.68 to 2.95 bits and 0.64 to 0.69 , respectively. Simpson's index range from 0.78 to 0.82 . Hamming distance range from 21 to 43 . Plantations provide ecosystem services with great importance on ornamental interest. The data collected in this study should be used for creating a floristic database. This database will be regularly updated for monitoring urban plantations. The information resulting from the monitoring will help to improve the urban forest management projects in the development plan.
\end{abstract}

Keywords: arid regions, biodiversity, shrubs, trees, urban plantations.

\section{INTRODUCTION}

The Algerian Sahara is known for its difficult climatic conditions. In this arid zone, the creation of green spaces is necessary to contribute to the quality of life and the attractiveness of cities (Laille et al., 2013). Therefore, it occupies an essential place in human life because of the many services and functions it provides to city inhabitants (Folega et al., 2020). Green space can take many forms, ranging from urban parks to grassed strips, including flowered roundabouts and alignment trees (Nomel et al., 2019).

Urban trees help regulate temperature, reduce energy consumption, improve urban air quality, reduce wind speeds, and mitigating the urban heat island effect (Waters et al., 2021). Urban trees also play a key role in climate change mitigation and global warming by capturing and storing atmospheric carbon dioxide, which is the largest contributor to greenhouse gases (Waters et al., 2021). Human actions coupled with climate change perturb and degrade the biological diversity of this ecosystem (Folega et al., 2020). 
Current Trends in Natural Sciences

Vol. 10, Issue 20, pp. 147-156, 2021

https://doi.org/10.47068/ctns.2021.v10i20.020

Current Trends in Natural Sciences (on-line)

In North Africa, research on green space has focused on floristic diversity and the evaluation of the sanitary status of alignment trees (Bekkouch et al., 2011; Dardourn et al., 2014). Trees inventory plays an important role in ameliorating our quality of life in the urban environment (Yimam and Kifle, 2020). The main objective of this study was to assess the floristic diversity of plantations (Trees and shrubs) in the municipality of Tamentit to ensure better plant species conservation planning.

\section{MATERIALS AND METHODS}

\subsection{Study Area}

The municipality of Tamentit is located at latitude $27^{\circ} 46^{\prime} \mathrm{N}$ and longitude $0^{\circ} 16^{\prime} \mathrm{W}$ in southwest Algeria. It is limited to the north by the municipality of Aougrout, to the south by the municipality of Fenoughil, in the east by the municipality of Tamekten, to the west by the commune of Adrar. It covers an area of $6937 \mathrm{~km}^{2}$ (Fig. 1).

The climate of Adrar region is characterized by a water deficit, due to low rainfall, intense evaporation, high temperatures and high luminosity; all these factors determine strong aridity (Toutain, 1979). Rainfall is low with an annual average of $9.7 \mathrm{~mm}$. Temperatures summer $46.2{ }^{\circ} \mathrm{C}$ in July, and $5.4{ }^{\circ} \mathrm{C}$ in January.

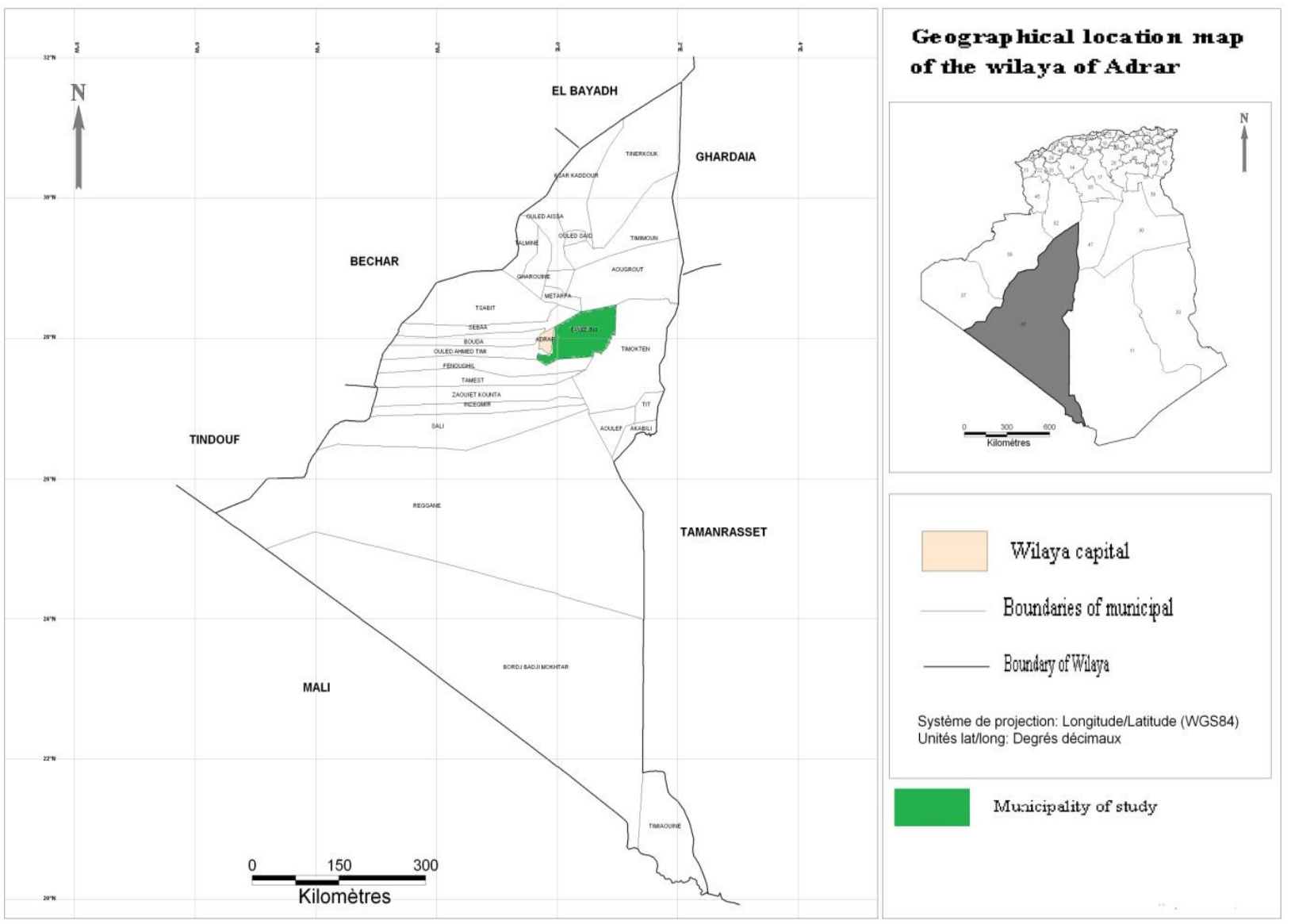

Figure 1. Geographical location of the study station (Tamentit, SW Algeria) 


\subsection{Data collection methods}

The plantations taken into account in the context of this study are:

alignment planting: located near the various roads and planted by the local authorities;

public Garden: public places on which trees are planted;

private Green spaces: which include gardens next to the houses. We note that the plantations are under the effect of anthropogenic activities that causes degradation and deforestation.

A floristic inventory was carried out in the three biotopes using an exhaustive sampling approach. It consisted in counting all the trees and shrubs found along the roads and the different public and private green spaces. The species are identified using the flora of Algeria (Quézel and Santa, 19621963), Flora vascular de Andaloucia oriental (Blanca et al., 2011).

The floristic composition was examined using: frequencies of botanical families and taxonomic classes of plant species; the naturalness of plant species (exotic or native). To account for the floristic diversity, the species richness, Shannon diversity index, Piélou index of evenness and Simpson index were calculated.

- The species richness $(\mathrm{S})$ is the number of species present in the environment studied.

- The Shannon-Weaver diversity index $\left(H^{\prime}\right)$ was calculated for each biotope as follows:

$$
\mathrm{H}=-\Sigma \text { pi } \log _{2} \mathrm{pi}
$$

it varies according to the number of species present and the relative proportion of individuals in various species, usually between 0 and Hmax $\approx 5$ bits, pi (between 0 and 1) is the relative proportion of the number of individuals of a species $i$ in the total number of individuals of all species concerned (pi $=$ ni / $\Sigma$ ni with ni as the number of individuals of species $\mathrm{i}$ and $\Sigma$ ni as all individuals of all species) (Osseni et al., 2020).

- The Piélou index of evenness (R): This index accompanies the Shannon diversity index to appreciate the distribution of species. It reflects the degree of diversity achieved by a plantation and corresponds to the ratio between the effective diversity $(\mathrm{H})$ and the theoretical maximum diversity $(\mathrm{H} \max ): \mathrm{R}=\mathrm{H} / \log _{2} \mathrm{~S}$.

The Piélou index varies between 0 and 1; it tends to 0 when almost all the numbers correspond to a single species of the population and tends to 1 when each of the species is represented by the same number of individuals (Osseni et al., 2020).

- The Simpson's diversity index (SDI) was determined for each biotope using the equation:

$$
\mathrm{SDI}=1-\frac{\Sigma \mathrm{n} *(\mathrm{n}-1)}{\mathrm{N}(\mathrm{N}-1)}
$$

Where $n=$ the total number of organisms of a particular species

$N=$ the total number of organisms of all species.

Simpson's diversity index ranging from 0 (communities with low diversity) to 1 for communities with higher diversity levels (Hammond and Pokorny, 2020).

- The difference between the flora is calculated by Hamming distance: $\mathrm{H}=1-\mathrm{J}$; where $\mathrm{J}$ is the Jaccard community coefficient equal to the ratio of the number of common species to the total number of species (Daget et al., 2003). The following qualifications should be used:

- Very low floristic difference for $\mathrm{H}<20$;

- Low $20 \leq \mathrm{H}<40$;

- Average $40 \leq \mathrm{H}<60$;

- Strong $60 \leq \mathrm{H}<80$;

- Very strong $80 \leq \mathrm{H}$ (Daget et al., 2003). 
- To appreciate the ecosystem services associated with plant floristic diversity, the classification of the forms of use of each species was determined from the book of Le Houérou (1995). For the species, Phoenix dactylifera, Lawsonia inermis, Gossypium herbaceum, the classification of forms of use has been determined based on the knowledge of the local population.

- Statistical treatment is a tool that can help us determine the relationship that may exist between the biotope and vegetation. These statistical treatments were carried out using the "Minitab 16" software (Souddi and Bendi-djelloul-Ghezlaoui, 2021).

\section{RESULTS AND DISCUSSIONS}

\subsection{Floristic composition and species diversity of plantations}

The floristic inventory made it possible to count 23 plant species divided into 22 genera and 17 families in the municipality of Tamentit (Table 1). This value is in the range of 17 to 53 families founded in the urban area of African regions (Dardourn et al., 2014; Agbelade et al., 2017; Nero et al., 2018; Fousséni et al., 2019; Nomel et al., 2019; Moussa et al., 2020; Osseni et al., 2020; Sogbossi et al., 2020). The comparison of the present floristic list with the previous works of (Bekkouch et al., 2011; Dardourn et al., 2014) revealed that 4 to 7 common species. Their resistance to environmental stress would explain this resemblance of these plant species.

The floristic richness distributed between two major taxonomic classes with $95.65 \%$ of eudicots and $4.35 \%$ of monocots. The high proportion of eudicots in urban flora had also been reported in previous works (Raoufou et al., 2011; Dardourn et al., 2014; Sogbossi et al., 2020). The low diversity of monocots is explained by the fact that this class contains only a small number of tree species adapted to the urban environment (Bekkouch et al., 2011).

The most represented families in three biotopes were Fabaceae (17.38\% of plant species), Arecaceae, Lythraceae and Tamaricaceae ( $8.69 \%$ of plant species). The other families have a low percentage $(4.35 \%)$ and are generally mono-generic and mono-specific. This indicates that these families have adapted to the environmental conditions of the municipality, as some authors have pointed out (Kombate et al., 2020; Nomel et al., 2019; Nomel et al., 2021).

The predominant species are Phoenix dactylifera with 1844 individuals (25.66\%), Tamarix aphylla with 1379 individuals (19.19\%), Dodonaea viscosa with 1004 individuals (13.97\%) and Leucaena leucocephala with 992 individuals (13.8\%) (Table 1). The choice of these species is due to the speed of their growth and the shading they create. Thus, the search for aesthetics strongly influences the selection of these species (Nomel et al., 2021).

The exotic plant species $(56.52 \%)$ are superior to native species $(43.48 \%)$. They have been introduced into plantations by foresters in reforestation programs, or by the local population. The abundance of exotic species can be explained by the fact that these species have a decorative contribution (Nomel et al., 2021). The high proportion of exotic plant species could fundamentally alter the structure and function of the urban ecosystem (De Bruyn, 2016; Kimpouni et al., 2020). The exotic plant species influenced the conservation of native species and the disappearance of several animal species, which depended on them (Moussa et al., 2020). The development of indigenous plant species in urban green spaces would greatly help in the conservation of local plant diversity in urban ecosystems (Sehoun et al., 2021). 


\section{Current Trends in Natural Sciences}

Vol. 10, Issue 20, pp. 147-156, 2021

https://doi.org/10.47068/ctns.2021.v10i20.020

Current Trends in Natural Sciences (on-line)

Table 1. List of plant species present in the study area

\begin{tabular}{|c|c|c|c|c|c|c|c|}
\hline \multirow[b]{2}{*}{ Family } & \multirow[b]{2}{*}{ Scientific Name } & \multirow[b]{2}{*}{ Code } & \multirow[b]{2}{*}{ Naturalness } & \multirow[b]{2}{*}{ Usage } & \multicolumn{3}{|c|}{ Green spaces abundance } \\
\hline & & & & & $\begin{array}{c}\text { Alignment } \\
\text { planting }\end{array}$ & $\begin{array}{l}\text { Public } \\
\text { garden }\end{array}$ & $\begin{array}{c}\text { Private green } \\
\text { spaces }\end{array}$ \\
\hline $\begin{array}{c}\text { Apocynaceae } \\
(4.35 \%)\end{array}$ & Nerium oleander $\mathrm{L}$. & No & Native & $\mathrm{O}$ & 194 & 2 & 23 \\
\hline Arecaceae & Phoenix dactylifera $\mathrm{L}$. & $P d$ & Native & Ind, Fr & 613 & 215 & 1016 \\
\hline$(8.69 \%)$ & Washingtonia filifera (Linden ex André) H.Wendl. ex de Bary & Wf & Exotic & $\mathrm{O}$ & 13 & I & 26 \\
\hline $\begin{array}{c}\text { Casuarinaceae } \\
(4.35 \%)\end{array}$ & Casuarina equisetifolia $\mathrm{L}$. & $\mathrm{Ce}$ & Exotic & $\mathrm{F}, \mathrm{O}$ & 24 & 203 & 32 \\
\hline $\begin{array}{c}\text { Euphorbiaceae } \\
(4.35 \%)\end{array}$ & Ricinus communis $\mathrm{L}$. & $\mathrm{Rc}$ & Native & $\mathrm{O}$ & 28 & I & 22 \\
\hline \multirow{4}{*}{$\begin{array}{l}\text { Fabaceae } \\
(17.38 \%)\end{array}$} & Leucaena leucocephala (Lam.) de Wit & L 1 & Exotic & $\mathrm{F}, \mathrm{S}, \mathrm{O}$ & 496 & 55 & 441 \\
\hline & Prosopis juliflora (Sw.) DC. & $\mathrm{Pj}$ & Exotic & $\mathrm{S}, \mathrm{O}$ & 28 & 1 & 4 \\
\hline & Acacia farnesiana $(\mathrm{L}$.$) Willd.$ & Af & Exotic & $\begin{array}{l}\mathrm{F}, \mathrm{S} \\
\mathrm{O}, \mathrm{B}\end{array}$ & 1 & 17 & I \\
\hline & Parkinsonia aculeata $\mathrm{L}$. & $\mathrm{Pa}$ & Exotic & $\mathrm{S}, \mathrm{O}, \mathrm{B}$ & 1 & 1 & 69 \\
\hline Lythraceae & Lawsonia inermis $\mathrm{L}$. & $\mathrm{Li}$ & Exotic & Ind, $O$ & 39 & 1 & 144 \\
\hline$(8.69 \%)$ & Punica granatum $\mathrm{L}$. & $\mathrm{Pg}$ & Exotic & $\mathrm{Fr}, \mathrm{O}$ & 5 & 2 & 1 \\
\hline $\begin{array}{c}\text { Malvaceae } \\
(4.35 \%)\end{array}$ & Gossypium herbaceum $\mathrm{L}$. & G h & Exotic & $\mathrm{O}$, Ind & 112 & 23 & 314 \\
\hline $\begin{array}{c}\text { Moraceae } \\
(4.35 \%)\end{array}$ & Ficus carica $\mathrm{L}$. & $\mathrm{Fc}$ & Native & Fr & 51 & 36 & 13 \\
\hline $\begin{array}{c}\text { Moringaceae } \\
(4.35 \%)\end{array}$ & Moringa oleifera Lam. & Mo & Exotic & $\mathrm{O}$ & 66 & I & 96 \\
\hline $\begin{array}{c}\text { Myrtaceae } \\
(4.35 \%)\end{array}$ & Eucalyptus camaldulensis Dehnh. & Ec & Exotic & $\mathrm{F}, \mathrm{B}$ & 9 & 26 & 11 \\
\hline $\begin{array}{c}\text { Oleaceae } \\
(4.35 \%)\end{array}$ & Olea europaea $\mathrm{L}$. & $\mathrm{Oe}$ & Native & $\begin{array}{l}\mathrm{S}, \mathrm{O}, \\
\text { Ind }\end{array}$ & 34 & I & 100 \\
\hline $\begin{array}{c}\text { Rhamnaceae } \\
(4.35 \%)\end{array}$ & Ziziphus lotus (L.) Lam. & $\mathrm{Z} 1$ & Native & $\mathrm{Fr}, \mathrm{O}$ & 19 & 7 & 11 \\
\hline $\begin{array}{c}\text { Sapindaceae } \\
(4.35 \%)\end{array}$ & Dodonaea viscosa (L.) Jacq. & D v & Exotic & $\mathrm{O}$ & 316 & 56 & 632 \\
\hline Tamaricaceae & Tamarix aphylla (L.) H. Karst. & Ta & Native & $\mathrm{F}, \mathrm{O}$ & 925 & 450 & 4 \\
\hline$(8.69 \%)$ & Tamarix gallica $\mathrm{L}$. & $\mathrm{Tg}$ & Native & $\mathrm{O}$ & 37 & 101 & 13 \\
\hline $\begin{array}{c}\text { Verbenaceae } \\
(4.35 \%)\end{array}$ & Lantana camara $\mathrm{L}$. & $\mathrm{Lc}$ & Exotic & $\mathrm{O}$ & I & I & 2 \\
\hline $\begin{array}{l}\text { Vitaceae } \\
(4.35 \%)\end{array}$ & Vitis vinifera $\mathrm{L}$. & $\mathrm{Vv}$ & Native & Fr & I & I & 5 \\
\hline $\begin{array}{c}\text { Zygophyllaceae } \\
(4.35 \%)\end{array}$ & Balanites aegyptiaca $(\mathrm{L}$.) Delile & B a & Native & $\mathrm{O}, \mathrm{S}$ & 1 & I & 3 \\
\hline Total & & & & & 3010 & 1195 & 2981 \\
\hline
\end{tabular}

Usage: F: Forest; B: Beekeeping; O: Ornamental; S: Sylvo-pastoral; Ind: Industrial; Fr: Fruit. 


\subsubsection{Floristic diversity of private green spaces}

The plant population of private green spaces is composed of 21 species, divided into 17 families. The most represented families in private green spaces are: Fabaceae (14.28\%), Arecaceae and Tamaricaceae (9.52\%) (Fig. 2). Phoenix dactylifera (34.08\%), Dodonaea viscosa (21.2\%) and Leucaena leucocephala (14.79\%) are the dominant species (Fig. 3). The private green spaces are environments that could constitute reservoirs of species and interesting environments (Nomel et al., 2021). The difference between the flora of private green spaces and public gardens by calculating the Hamming distance is average, i.e. $(\mathrm{H}=43)$. The Simpson index calculated for private green space is 0.80 . This can be explained by the higher species richness.

\subsubsection{Floristic diversity of alignment planting}

The alignment planting is composed of 19 species, divided into 14 families. The dominant families are Fabaceae (15.79\%), Arecaceae, Lythraceae and Tamaricaceae (10.53\%) (Fig. 2). This plantation is dominated by Tamarix aphylla (30.73\%), Phoenix dactylifera $(20.36 \%)$ and Leucaena leucocephala (16.48\%) (Fig. 3). The diversity in alignment planting is poor. The authorities have cultivated the alignment planting for their shade, landscape aesthetics and carbon sequestration (Osseni et al., 2020). The difference between the flora of alignment planting and the private green spaces by calculating the Hamming distance is low, i.e. $(\mathrm{H}=26)$. The Simpson index calculated for alignment planting is 0.82 . This can be explained by a high level of diversity.

\subsubsection{Floristic diversity of public gardens}

The floristic richness of the public garden is composed of 15 species grouped into 11 families. The low specific richness observed in the public garden reflects the intensity of uncontrolled human activities which has had an impact on diversity, the reduction in the number of species and density (Sehoun et al., 2020). The Fabaceae (20\%), Lythraceae and Tamaricaceae (13.33\%) are the dominant families (Fig. 2). This plantation is dominated by Tamarix aphylla (37.66\%), Phoenix dactylifera (17.99\%) and Casuarina equisetifolia (16.99\%) (Fig. 3). The difference between the flora of the public garden and the alignment planting by calculating the Hamming distance is low, i.e. $(\mathrm{H}=21)$. The Simpson index calculated for the public garden is 0.78 . This value indicates the level of diversity.

\subsubsection{Species diversity}

The Shannon index calculated for private green spaces is 2.82 bits; for alignment planting is 2.95 bits and in the public garden is 2.68 bits. These results are consistent with those obtained by (Bekkouch et al., 2011; Dardourn et al., 2014; Nero et al., 2018; Moussa et al., 2020; Nomel et al., 2021) who found that the value of Shannon's diversity index varied between 2.45 to 3.72 bits.

The evenness value is 0.64 for private green spaces, in alignment planting and in the public garden is 0.69 . The value of the evenness is much higher than the value of 0.54 to 0.60 reported in Niamey and Maradi Cities (Moussa et al., 2020) and Abuja City (Agbelade et al., 2017).

The distribution of species, species richness and diversity indices have most often depended on the abundance and quality of habitats (Bogaert and Andre, 2013), climatic and edaphic factors of the environment (Faye et al., 2015) and human intervention (Kombate et al., 2020). 


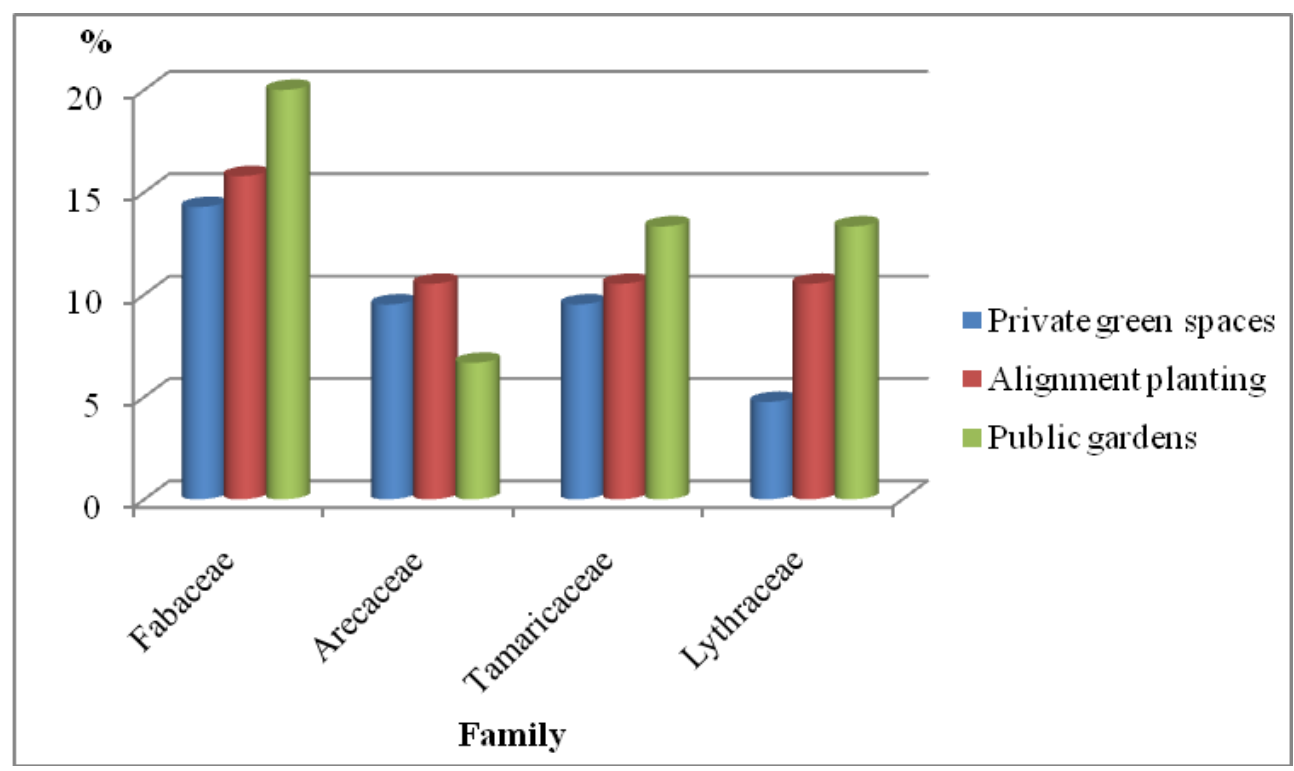

Figure 2. Dominant families in three biotopes

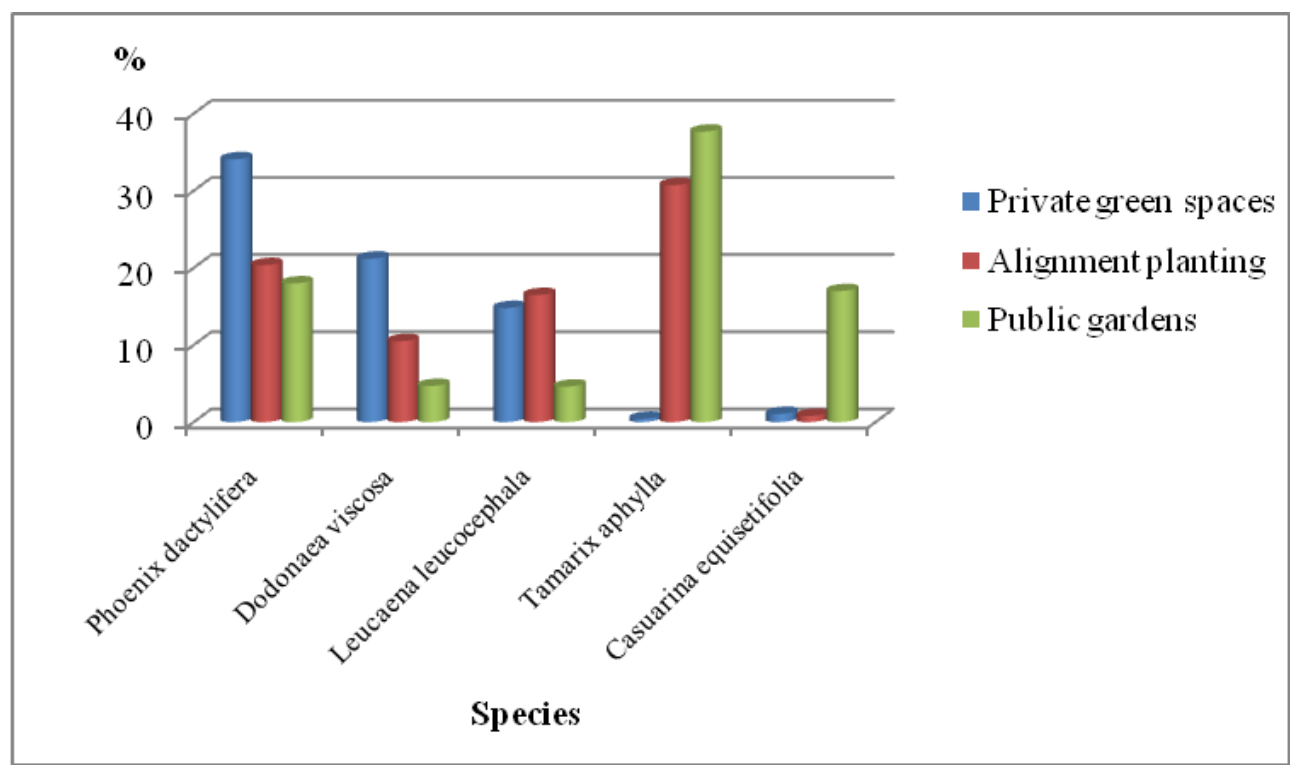

Figure 3. Dominant species in three biotopes

\subsection{Use of phytodiversity}

Trees and shrubs offer many services to the population. These services come from the forms of the use of organs or parts of plants. However, it should be noted that some species refer to one or more uses. The following categories have been identified (Table 1):

$>$ Single-use species (9 species) that are: Nerium oleander, Washingtonia filifera, Ricinus communis, Moringa oleifera, Dodonaea viscosa, Tamarix gallica, Lantana camara, Ficus carica, Vitis vinifera; 


\section{Current Trends in Natural Sciences}

Vol. 10, Issue 20, pp. 147-156, 2021

https://doi.org/10.47068/ctns.2021.v10i20.020

Current Trends in Natural Sciences (on-line)

Double use species (10 species) are Phoenix dactylifera, Casuarina equisetifolia, Prosopis juliflora, Lawsonia inermis, Punica granatum, Gossypium herbaceum, Eucalyptus camaldulensis, Ziziphus lotus, Tamarix aphylla, Balanites aegyptiaca.

> Triple use species (3 species) are Leucaena leucocephala, Parkinsonia aculeata, Olea europaea.

Multiple-use species (1 species) is Acacia farnesiana.

\subsection{Statistical Treatment}

Lantana camara, Parkinsonia aculeata and Phoenix dactylifera are species closer to private green spaces. The species close to private green spaces can be explained by the adaptation of these species to the climatic and edaphic conditions of the municipality. Also, Lawsonia inermis and Moringa oleifera were cultivated near houses for the purpose of providing elements useful in domestic uses. The species close to the alignment planting can be explained by the ornamental and decorative appearance of these plants. They offer a spectacle of beauty either by their foliage or by their flowers.

Nerium oleander and Prosopis juliflora, are species close to alignment planting. Tamarix gallica, Acacia farnesiana, Casuarina equisetifolia and Eucalyptus camaldulensis, are species close to the public garden. A species close to public gardens are generally trees that can provide shade in all seasons (Le Blanc and Malaisse, 1978). The services of the species recorded present socioeconomic or potential interests for planting in arid zones (Le Houérou, 1995).

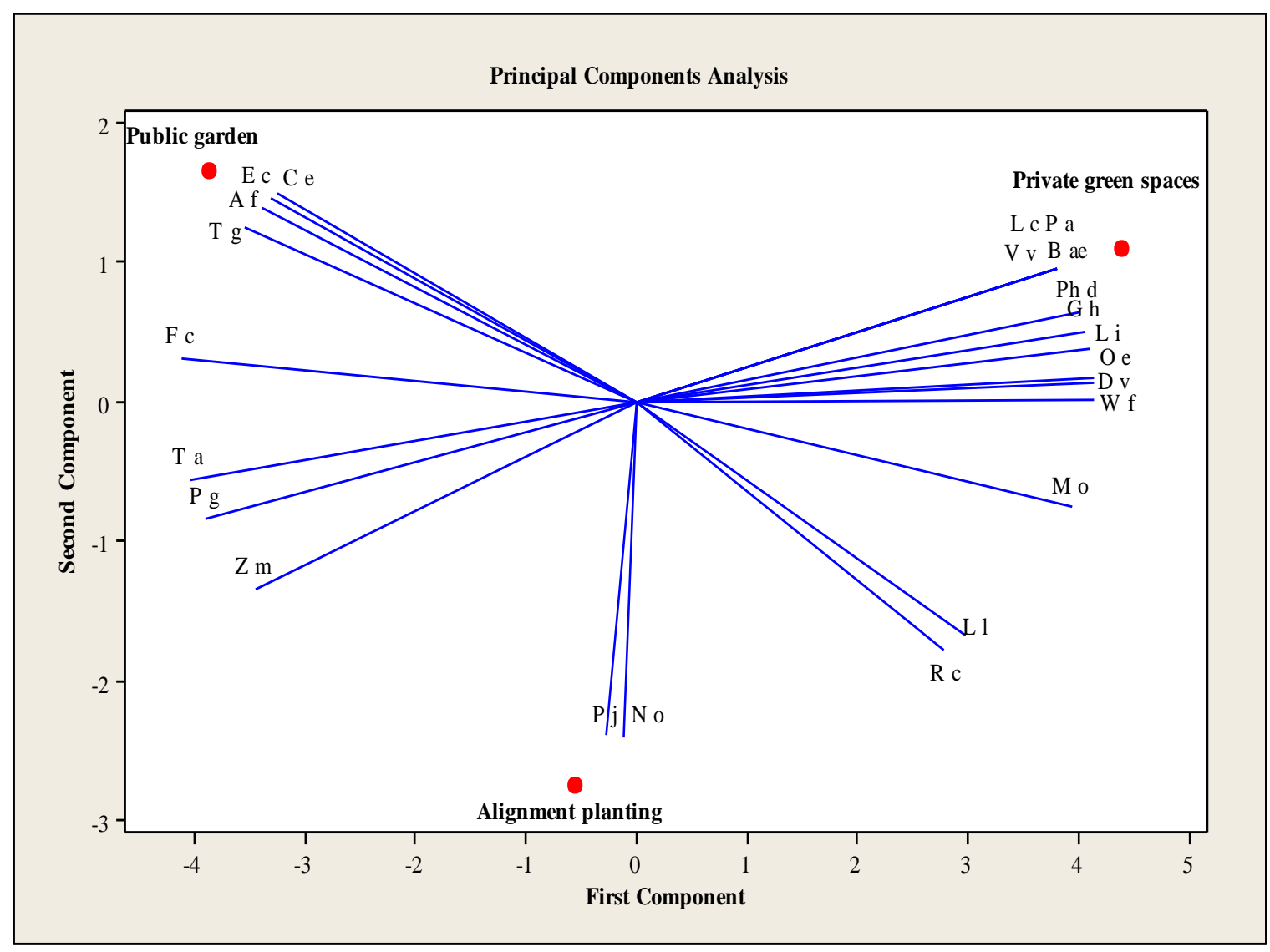

Figure 3. Biotope-Species relationship in the urban plantations studied 


\section{CONCLUSIONS}

This study provided important information on the flora of the municipality of Tamentit. This flora is composed of 23 species divided into 17 families. The distribution of these species in the major taxonomic groups indicates that the eudicots are mostly represented by preferential species of the families of Fabaceae. For monocots, only one family present is the Arecaceae. The composition and diversity of plants species differed relatively between biotopes. The ranges of diversity indices observed in the three biotopes were: Shannon's diversity index (2.68-2.95), Evenness index (0.640.69), Simpson diversity index (0.78-0.82), and Hamming distance (21-43). The flora is mixed (56.52\% of exotic species versus $43.48 \%$ of native species). The planting of local species (native) should be encouraged, especially those of great value to the local and national economy, by the formation and public awareness for sustainable development. Education and public awareness of the benefits and ecosystem services of urban flora were important aspects of maintaining plant species diversity (Agbelade et al., 2017).

\section{REFERENCES}

Agbelade, A.D., Onyekwelu, J.C., Oyun, M. B. (2017). Tree Species Richness, Diversity, and Vegetation Index for Federal Capital Territory, Abuja, Nigeria. International Journal of Forestry Research, 1, 1-12. https://doi.org/10.1155/2017/4549756.

Bekkouch, I., Kouddane N., Daroui E., Boukroute A., Berrichi A. (2011). Inventaire des arbres d'alignement de la ville d'Oujda [Inventory of alignment trees in the city of Oujda]. Nature \& Technologie, 5, 87-91.

Blanca, G., Cabezudo, B., Cueto, M., Salazar C., Morales Torres, C. (2011). Flora vascular de Andalucía oriental. $2^{\text {nd }}$ Edition. Universidades de Almería, Granada, Jaén y Málaga, Granada. pp 1751.

Bogaert, J., Andre, M. (2013). Ecologie du paysage en Afrique subsaharienne [Landscape ecology in sub-Saharan Africa]. Tropicultura, 31(1), 1-2.

Daget, P., Gaston, A., Forgiarini, G. (2003). Comparer des relevés de dates différentes au même emplacement. Exemple du Tchad [Compare records from different dates at the same location. Example from Tchad]. Revue d'élevage et de médecine vétérinaire des pays tropicaux, 56(3-4), 163-166. doi: 10.19182/remvt.9859.

Dardourn, M., Darouin, E., Boukroute, A., Kouddane, N.E., Berrichi, A. (2014). Inventaire et état sanitaire des arbres d'alignement de la ville de Saïdia (Maroc oriental) [Inventory and sanitary status of alignment trees in the city of Saïdia (eastern Morocco)]. Nature \& Technologie, 10, 2-9.

De Bruyn, O.D. (2016). Exotic plant species and environmental vulnerability: an old debate? The case study of Belgium (from the end of the 18th century to the 1950ies). VertigO. 16(3), 1-22.

Faye, C., Sow, A.A., Ndong, J.B. (2015). Étude des sècheresses pluviométriques et hydrologiques en Afrique tropicale : caractérisation et cartographie de la sècheresse par indices dans le haut bassin du fleuve Sénégal [Study of pluviometric and hydrological droughts in tropical Africa: characterization and mapping of drought by indices in the upper basin of the Senegal River]. Géographie physique et environnement, 9, 17-35. https://doi.org/10.4000/physio-geo.4388.

Folega, F., Kombate, B., Konate, D., Kanda, M., Wala, K., Akpagana, K. (2020). Inventaire et séquestration de carbone de la végétation de l'emprise urbaine de la ville de Dapaong, Togo [Inventory and carbon sequestration of the vegetation of the urban influence of the city of Dapaong, Togo]. Espace géographique et société Marocaine, 41/42, 273-289.

Fousséni, F., Wouyo, A., Madjouma, K., Djibril, K., Kissao, G., Kperkouma, W., Koffi, A. (2019). Flore des espaces verts urbains de la ville d'Atakpamé au Togo [Flora of urban green space of Atakpame city in Togo]. Synthèse : Revue des Sciences et de la Technologie, 25(2), 25-39.

Hammond, E.M., Pokorny, R. (2020). Diversity of Tree Species in Gap Regeneration under Tropical Moist SemiDeciduous Forest: An Example from Bia Tano Forest Reserve. Diversity, 12(8), 301. https://doi.org/10.3390/d12080301.

Kimpouni, V., Nzila, J.D., Watha-Ndoudy, N., Kokolo Bilongo, C.E., Yallo, M.S., Kampe, J.P., Louembe, D. (2020). Sociocultural and Ecological Dynamics of Green Spaces in Brazzaville (Congo). International Journal of Ecology, 1-12. https://doi.org/10.1155/2020/3719267. 


\section{Current Trends in Natural Sciences}

Vol. 10, Issue 20, pp. 147-156, 2021

https://doi.org/10.47068/ctns.2021.v10i20.020

Current Trends in Natural Sciences (on-line)

ISSN: 2284-953X

Current Trends in Natural Sciences (CD-Rom)

ISSN: 2284-9521

ISSN-L: 2284-9521

ISSN-L: 2284-9521

Kombate, B., Dourma, M., Folega, F., Woegan, A.Y., Wala, K., Akpagana, K. (2020). Diversité floristique et caractérisation structurale des formations boisées du domaine Soudano-Guinéen au Centre du Togo [Floristic diversity and structural characterization of woodlands in the Soudano-Guinean domain in Central Togo]. Afrique Science, 17(6), 29-43.

Laïlle, P., Provendier, D., Colson F., Salanie, J. (2013). Les bienfaits du végétal en ville [The benefits of plants in the city]. Synthèse des travaux scientifiques et méthode d'analyse, Plante \& Cité, Angers, $31 \mathrm{pp}$.

Le Houérou, H.N. (1995). Bioclimatologie et biogéographie des steppes arides du Nord de l'Afrique : diversité biologique, développement durable et désertisation [Bioclimatology and biogeography of the arid steppes of north Africa: biological diversity, sustainable development and desertization]. In : Le Houérou H.-N. (ed.). Bioclimatologie et biogéographie des steppes arides du Nord de l'Afrique : diversité biologique, développement durable et désertisation. Montpellier : CIHEAM, pp. 1-396 (Options Méditerranéennes : Série B. Etudes et Recherches ; n 10).

Le Blanc, M., Malaisse, F. (1978). Lubumbashi, un écosystème urbain tropical [Lubumbashi, a tropical urban ecosystem], Centre International de Semiologie, Université National du Zaïre. 178 pp.

Moussa, S., Kuyah, S., Kyereh, B., Tougiani, A., Mahamane, S. (2020). Diversity and structure of urban forests of Sahel cities in Niger. Urban Ecosystems, 23, 851-864. https://doi.org/10.1007/s11252-020-00984-6.

Nero, B.F., Campion, B.B., Agbo, N., Callo-Concha, D., Denich, M. (2017). Tree and trait diversity, species coexistence, and diversity-functional relations of green spaces in Kumasi, Ghana. Procedia engineering, 198, 99-115. https://doi.org/10.1016/j.proeng.2017.07.164.

Nero, B.F., Nana Afranaa, K., Jatta, r., Fatunbi O. (2018). Tree Species Diversity and Socioeconomic Perspectives of the Urban (Food) Forest of Accra, Ghana. Sustainability, 10(10), 3417. https://doi.org/10.3390/su10103417.

Nomel, G. J.R., Kouassi, R.H., Ambe, A.S.A., Kouadio, Y.J.C., Doumbia, M., N'guessan, K.E. (2019). Diversité et stock de carbone des arbres d'alignement : Cas d'Assabou et Dioulakro de la ville de Yamoussoukro (Centre de la Côte d'Ivoire) [Diversity and carbon stock of alignment trees: Case of Assabou and Dioulakro from the city of Yamoussoukro (Central Côte d'Ivoire)]. IOSR Journal of Environmental Science, Toxicology and Food Technology, 13(4), 84-89. doi: 10.9790/2402-1304018489.

Nomel, G.J.R., Kouassi R.H., Ambe, A.S.A., Doumbia, M., N'guessan K.E. (2021). Étude de la végétation des jardins privés de la ville de Yamoussoukro (Centre, Côte d'Ivoire) [Study of the vegetation of private gardens in the city of Yamoussoukro (Center, Côte d'Ivoire)]. Nature et Technologie, 13(1), 91-98.

Osseni, A.A., Gbesso, G.H.F., Nansi, k. M., Tente, A.B.H. (2020). Phytodiversité et services écosystémiques associés aux plantations d'alignement des rues aménagées de la ville de Grand-Popo au Bénin [Phytodiversity and ecosystem services associated with avenue trees planted along managed roadways in the city of Grand-Popo in Benin]. Bois et Forêts des Tropiques, 345(3), 85-97. https://doi.org/10.19182/bft2020.345.a31808.

Quézel, P., Santa, S. (1962-1963). Nouvelle flore de l'Algérie et des régions désertiques méridionales. Edition du Centre National de la Recherche Scientifique [New flora of Algeria and southern desert regions]. Paris: Ed. C.N.R.S. 2 Vol, 1170p.

Raoufou, R., Kouami, K., Koffi, A. (2011). Woody plant species used in urban forestry in West Africa: Case study in Lome, capital town of Togo. Journal of Horticulture and Forestry, 3(1), 21-31. https://doi.org/10.5897/JHF.9000120.

Sehoun, L.C., Osseni, A.A., Orounladji, M., Lougbegnon, T.O., Codjia, J.C.T. (2021). Diversité floristique des formations végétales urbaines au Sud du Bénin (Afrique de l'Ouest) [Floristic diversity of urban plant formations in southern Benin (West Africa)]. Revue Marocaine des Sciences Agronomiques et Vétérinaires. 9(2), 266-273.

Sogbossi, E.S., Zakari, S., Djego, J.G. (2020). Phytodiversity and Spatial Development of Urban Flora in Lokossa, Benin. International Journal of Natural Resource Ecology and Management, 5(4), 145-159. doi: 10.11648/j.ijnrem.20200504.12.

Souddi, M., Bendi-Djelloul-Ghezlaoui, B.D. (2021). Application of a new model bioclimatic classification in Tlemcen region (Northwest Algeria). Analele Universităţii din Oradea, Fascicula Biologie. 28(1), 14-19.

Toutain G. (1979). Éléments d'agronomie Saharienne [Elements of Saharan agronomy]. Cellules des zones arides, Inst. nat. de la recherche agronomique, Groupe de recherche et d'echanges technologiques.

Waters, E., Oghaz, M.M., Saheer, L. B. (2021). Urban Tree Species Classification Using Aerial Imagery. arXiv preprint arXiv:2107.03182. Proceedings of the 38th International Conference on Machine Learning, Vienna, Austria.

Yimam, Y.M., Kifle, B. (2020). Tree Inventory Assessment in Religious Institution Compound and its Benefit for Environmental Management in the Case of Addis Ababa, Ethiopia. International Journal of Scientific Research in Biological Sciences, 7(1), 51-61. 